\title{
Construction of the granitoid crust of an island arc part I Geochronological and geochemical constraints from the plutonic Kohistan (NW Pakistan)
}

\section{Journal Article}

Author(s):

Jagoutz, Oliver; Burg, Jean-Pierre; Hussain, S.; Dawood, H.; Pettke, Thomas; lizuka, T.; Maruyama, S.

Publication date:

2009

Permanent link:

https://doi.org/10.3929/ethz-b-000018897

Rights / license:

In Copyright - Non-Commercial Use Permitted

Originally published in:

Contributions to Mineralogy and Petrology 158(6), https://doi.org/10.1007/s00410-009-0408-3 


\title{
Construction of the granitoid crust of an island arc part I: geochronological and geochemical constraints from the plutonic Kohistan (NW Pakistan)
}

\author{
Oliver E. Jagoutz $\cdot$ J.-P. Burg $\cdot$ S. Hussain · \\ H. Dawood $\cdot$ T. Pettke $\cdot$ T. Iizuka $\cdot$ S. Maruyama
}

Received: 10 June 2008/Accepted: 21 April 2009/Published online: 31 May 2009

(C) Springer-Verlag 2009

\begin{abstract}
We present major and trace element analyses and $\mathrm{U}-\mathrm{Pb}$ zircon intrusion ages from I-type granitoids sampled along a crustal transect in the vicinity of the Chilas gabbronorite of the Kohistan paleo-arc. The aim is to investigate the roles of fractional crystallization of mantlederived melts and partial melting of lower crustal amphibolites to produce the magmatic upper crust of an island arc. The analyzed samples span a wide calc-alkaline compositional range (diorite-tonalite-granodiorite-granite) and
\end{abstract}

Communicated by T. L. Grove.

Electronic supplementary material The online version of this article (doi:10.1007/s00410-009-0408-3) contains supplementary material, which is available to authorized users.

O. E. Jagoutz $(\bowtie) \cdot$ J.-P. Burg

Department of Earth Sciences, ETH and University Zurich,

Sonneggstrasse 5/NO, 8092 Zurich, Switzerland

e-mail: jagoutz@MIT.EDU

O. E. Jagoutz

Department of Earth, Atmospheric, and Planetary Sciences,

Massachusetts Institute of Technology, Cambridge, USA

S. Hussain · H. Dawood

Pakistan Museum of Natural History, Garden Avenue,

Shakarparian, Islamabad 44 000, Pakistan

T. Pettke

Department of Earth Sciences, University of Bern,

Baltzerstrasse 1+3, 3012 Bern, Switzerland

T. Iizuka

Research School of Earth Sciences, The Australian National

University, Mills Rd., Canberra, ACT 0200, Australia

\section{S. Maruyama}

Department of Earth and Planetary Sciences,

Tokyo Institute of Technology, Tokyo 152, Japan have typical subduction-related trace element signatures. Their intrusion ages $(75.1 \pm 4.5-42.1 \pm 4.4 \mathrm{Ma})$ are younger than the Chilas Complex $(\sim 85 \mathrm{Ma})$. The new results indicate, in conjunction with literature data, that granitoid formation in the Kohistan arc was a continuous rather than punctuated process. Field observations and the presence of inherited zircons indicate the importance of assimilation processes. Field relations, petrographic observations and major and trace element compositions of the granitoid indicate the importance of amphibole fractionation for their origin. It is concluded that granitoids in the Kohistan arc are derivative products of mantle derived melts that evolved through amphibole-dominated fractionation and intra crustal assimilation.

\section{Introduction}

The continental crust is generally assumed to be created in island arcs (Rudnick 1995), which mature toward a composition more akin to bulk continental crust (Ringwood 1974). A major difference between the "juvenile" and "mature" arc stages concerns the voluminous amount of granitoid formed in mature arcs (Baker 1968) which is also an important difference between continental and oceanic arcs. We make a difference, in mineralogical terms, between migmatitic-granitic rocks, mostly of metasedimentary origin and consisting of subequal amounts of plagioclase, alkali feldspar and quartz, and 'felsic' granitoids of the I-Type suite of diorite, tonalite, granodiorite, with subordinate granite. An unsolved paradox in the idea that continental crust forms in subduction zones is that bulk estimates of island-arc crust compositions are basaltic (DeBari and Sleep 1991; Holbrook et al. 1999) while the 
bulk continental crust is andesitic (Rudnick and Gao 2003). The voluminous occurrence of evolved rocks drives the average crustal arc composition toward andesitic. Accordingly, understanding the formation of evolved plutonic rocks should lead to further understanding of the continental crust formation. Despite wealthy research, no consensus exists. Among the several hypotheses put forward for granitoid formation in arcs, two are conflicting: (1) magmatic differentiation from a mafic magma is a single stage process (Bowen 1928); (2) partial melting of the basaltic (amphibolitic) lower crust triggered by magma addition invokes a multistage scenario (e.g. Pitcher 1997): initial basaltic underplating and hydration (amphibolitization) are followed by 'dehydration' due to subsequent underplating. Partial melting experiments on amphibolitized gabbros produce compositions akin to upper crustal granitoids and thus tend to support the second hypothesis. Partial melting leaves a dense garnet-bearing residue (e.g. Beard and Lofgren 1991) that eventually might delaminate (Jull and Kelemen 2001). This hypothesis is widely accepted since geochemical arguments point to the involvement of garnet in some granitoid rocks, especially in the Archean record. However, a major question concerns the heat supply needed for partial melting of the lower crust. Because of the high solidus temperature, fluid-absent melting of hornblende in metabasalt will not take place in collision zones without augmented heat input from the mantle (Thompson and Connolly 1995). To solve this difficulty, it has been proposed that heat comes either from asthenospheric upwelling during extension or from massive invasion and/or underplating of crust by mantle magma (e.g. Dufek and Bergantz 2005; Annen et al. 2006).

The link between geochemical signatures invoking garnet and a specific formation mechanism of granitoids is questionable. Fractional crystallization experiments have shown that garnet can be a magmatic phase in the lower crust at pressure and water content relevant to arcs (Green and Ringwood 1968; Green 1972, 1992; Müntener et al. 2001; Alonso-Perez et al. 2009). The oxygen isotopic record documents that granitoids have a hybrid origin with significant contributions from both the mantle and the crust (Kemp et al. 2007). The question of how much of the continental evolution involves re-melting of older crust versus fractionation of mantle derived, hydrous magmas is yet to be solved.

Research on granitoid formation in oceanic arcs is hampered by the facts that (1) trace and isotopic element signatures are only of limited use to infer the formation mechanism and (2) island arc sections including upper and lower crustal exposures are rare. Therefore, arc building processes are often inferred from surface information on lavas and sediments, which by no means are representative of the rocks forming the continental crust. The Kohistan paleo-arc in NW Pakistan (Figs. 1,2) offers one of the best-exposed sections through an oceanic arc from its mantle to the upper crustal volcanic and sedimentary levels (Tahirkheli 1979). Unlike other arc sections (e.g. Talkeetna, Alaska) it exposes massive volumes of granitoids, which are the objects of this study.

The plutonic part of the Kohistan arc includes the Chilas Complex, a huge mafic intrusion emplaced during intra arc extension (Khan et al. 1989; Burg et al. 2006; Jagoutz et al. 2006; Jagoutz et al. 2007). The Chilas Complex is so voluminous $(300 \times 40 \mathrm{~km}$, Fig. 1) that heat carried by this magma can be inferred to have exceeded the solidus of amphibolitic and water-saturated gabbroic rocks in the surrounding host rocks (Bard 1983). Accordingly, intrusion of the Chilas Complex could have provided a favorable environment for granitoid formation by partial melting. From this line of thoughts, we selected the area around the Chilas Complex as an optimum case to study the importance of partial melting versus fractional crystallization in magmatic arcs. We first document new field and geochemical evidence that constrains the geology of this area. We then present geochronological and geochemical data of granitoid and amphibolitic rocks in the Dir-Kalam and in the Chilas areas (Fig. 1). These areas expose a $\sim 15 \mathrm{~km}$ vertical transect through the crust, enabling the study of granitoid formation at various depths in the crust. The new data indicate that partial melting associated with the Chilas intrusion is negligible. Intrusion ages reveal that granitoids were formed during a steadily active process that we infer to be fractional crystallization of mantle-derived melts coupled with wall rock assimilation. These results demand re-evaluating the tectonic history of the Kohistan arc.

\section{Geological Setting}

\section{Kohistan geology}

The Kohistan terrane in NW Pakistan is separated from the Karakoram margin of Eurasia, to the north, by the Karakoram-Kohistan Suture and from the Indian Plate, to the south, by the Indus Suture (Fig. 1). The Kohistan is generally regarded as a Jurassic/Cretaceous island arc that was wedged between the Indian and Asian plates during collision between India and Asia (Tahirkheli 1979; Bard 1983). The intraoceanic arc originated above a northdipping subduction somewhere in the equatorial area of the Tethys Ocean, possibly near the Eurasian continental margin (Coward et al. 1987; Khan et al. 1993; Bignold and Treloar 2003). A minimum age for initiation of subduction is given by the $\sim 154$ Ma calc-alkaline Matum Das intrusion (Schaltegger et al. 2004). At $\sim 85 \mathrm{Ma}$, intra arc extension with associated decompression melting resulted in the intrusion of the Chilas Complex (Khan et al. 1989; 


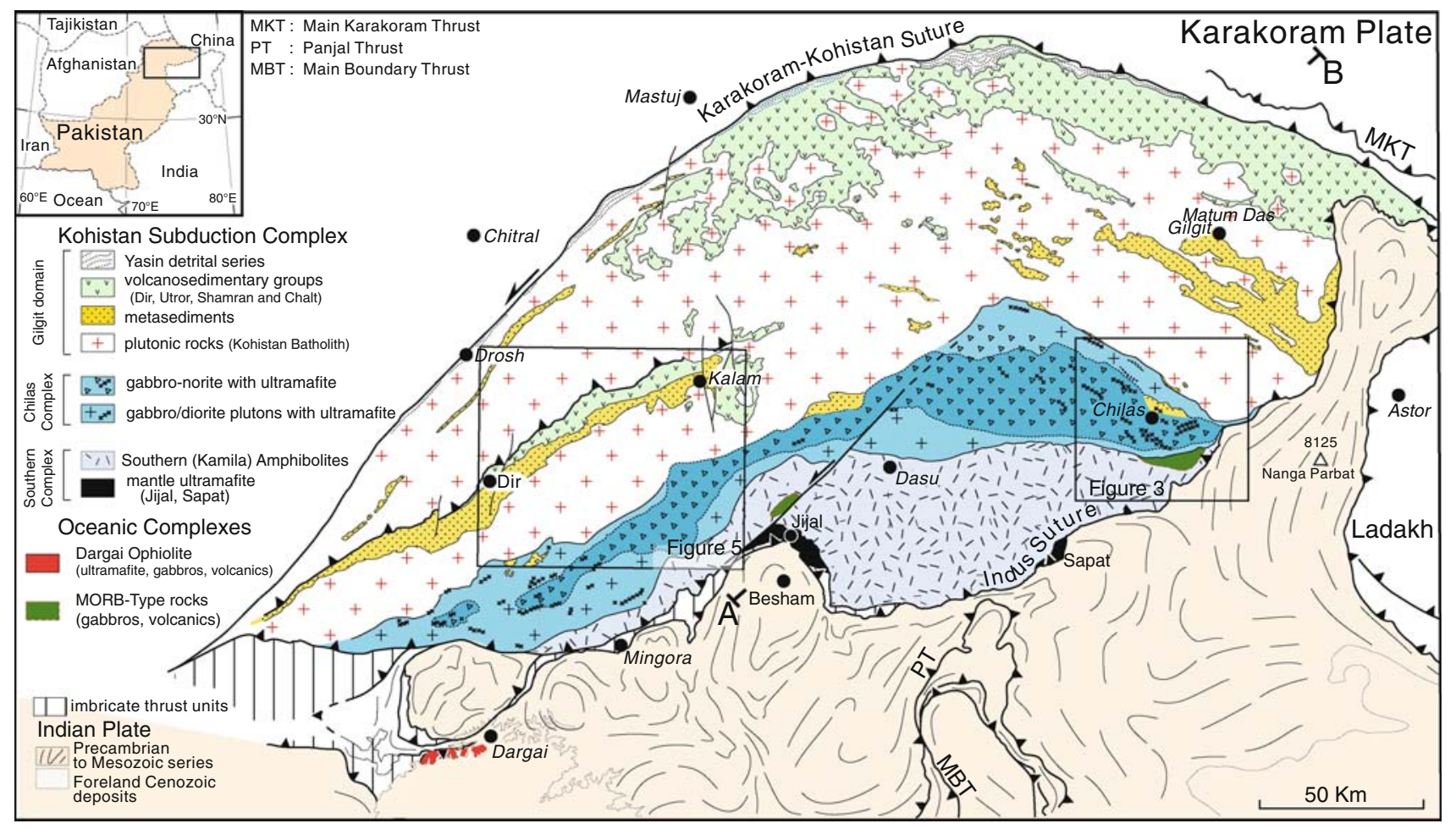

Fig. 1 Simplified geological map of the Kohistan Arc (work in progress). Frames = location of the studied Chilas and Dir-Kalam areas, Figs. 3 and 5, respectively. $A$ and $B$ indicate the location of the cross section presented in Fig. 2

Schaltegger et al. 2002; Burg et al. 2006; Jagoutz et al. 2006; Jagoutz et al. 2007). The timing of collision of the Kohistan arc with the Eurasian continent is contentious. Based on structural-metamorphic arguments, (Bard 1983) considers closure of the Karakoram-Kohistan Suture to postdate collision with India at $60-50 \mathrm{Ma}$, which is supported by paleomagnetic data (Khan et al. 2008). However, the opposite is inferred from structural observations and $\mathrm{Rb}-\mathrm{Sr}$ whole rock ages (Petterson and Windley 1985).

The arc is composed of three major plutonic-volcanic sections, from south to north: The Southern Plutonic Complex, the Chilas Complex and the Kohistan Batholith. The Southern Plutonic Complex comprises ultramaficmafic complexes (Jijal and Sapat) and the Southern (a.k. Kamila) Amphibolites representing the upper mantle and lower/middle crust of the island arc, respectively (Fig. 1) (e.g. Burg et al. 2005). The Chilas Complex, a large gabbronorite body enclosing $\mathrm{km}$-scale ultramafic bodies (Jagoutz et al. 2006, 2007) separates the southern part of the arc from the Kohistan Batholith. The southern and central Kohistan Batholith is primarily composed of plutonic rocks with screens of volcanic and sedimentary rocks and their metamorphosed equivalents (Petterson and Windley 1985; Pudsey et al. 1985) to which the Jaglot, Dir and Utror groups exposed in the southern part of the Batholith (Fig. 2) may belong. The Dir and Utror groups are dominantly basalts and andesites with subordinate volcano-clastic sediments and Eocene marine limestones (Sullivan et al. 1993). The volcanics show low grade metamorphism and yielded an ${ }^{39} \mathrm{Ar} /{ }^{40} \mathrm{Ar}$ hornblende age of $40 \mathrm{Ma}$ (Treloar et al. 1989). The northernmost Kohistan is dominated by volcano-sedimentary series variously named Chalt, Shamran and Yasin groups.

\section{Structure of the studied area}

The present-day exposure level from upper mantle to upper crustal sequences of the Kohistan arc is controlled by three main tectonic events: (1) intra-arc extension associated with the $85 \mathrm{Ma}$ Chilas intrusion within a south-dipping shear zone (Burg et al. 2006); (2) collision and obduction of Kohistan on the Indian lithosphere, between 65 and $45 \mathrm{Ma}$; and (3) the $4 \mathrm{Ma}$ to present rise of the Nanga Parbat Syntaxis (Zeitler et al. 1993), which lifted up deeper levels of Kohistan in the east than in the west.

\section{Analyzed samples}

We present geochronological and geochemical data from granitoids sampled along the southern margin of the Kohistan Batholith, close to the contact with the Chilas Complex. Three locations represent three crustal depths (Fig. 1): the eastern part of the arc, near the Chilas Township (Figs. 3, 4) is the deepest; the intermediate area is near 
Fig. 2 Cross-section through the Kohistan arc modified after (Burg et al. 2006). Lithology as in Fig. 1

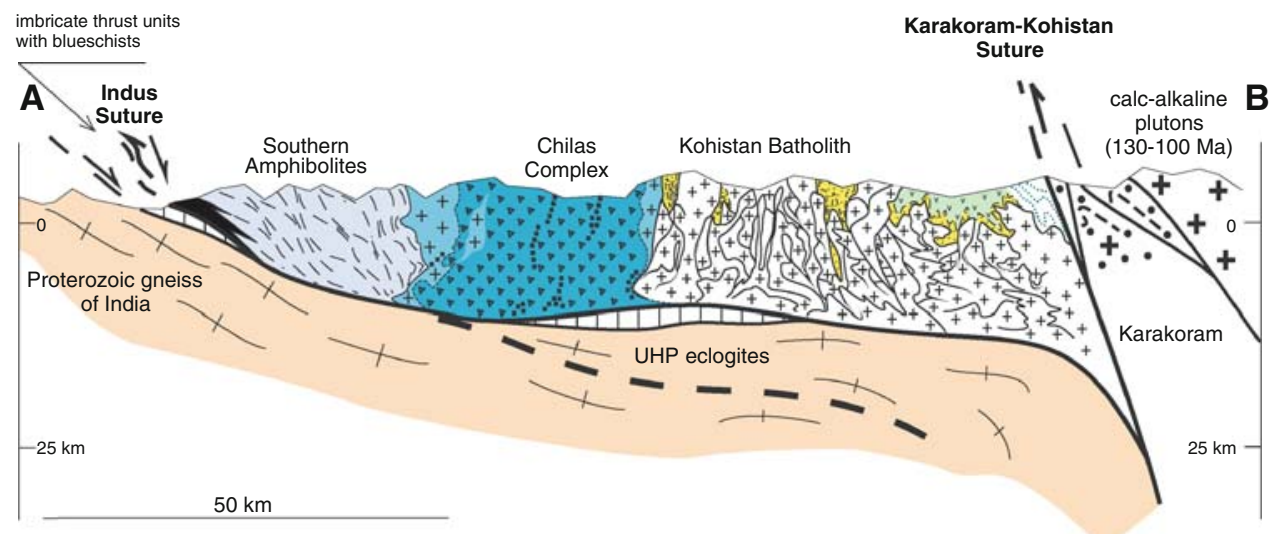

Kalam; and the Dir area is shallowest (Figs. 1, 5). The pressure difference from Chilas to Dir is $\sim 5$ kbar (unpublished geothermobarometry): we additionally present geochemical analyses of migmatitic meta-greywacke and leucosome, amphibolite and metagabbro from the Chilas location (Fig. 3). Partial melting in these rocks is related to the Chilas intrusion. Precise location and petrographic descriptions of the dated samples are given in appendix.

\section{Analytical methods}

Zircon separation followed standard techniques using heavy liquid separation. 30 to 100 zircons were mounted in epoxy and polished. Before $\mathrm{U}-\mathrm{Pb}$ analysis, the internal structure of the zircons were examined by cathodoluminescence (CL) using a JEOL JSM-5310 scanning electron microscope combined with an Oxford CL system at Tokyo Institute of Technology. U-Pb ages were analyzed following the method of (Iizuka and Hirata 2004) using laser ablation ICPMS system (VG plasmaQuad 2 quadropole coupled with a GeoLas 200CQ laser ablation system). Detailed of the setup and the analytical procedure are given in (lizuka and Hirata 2004) and in the electronic appendix.

Whole rock major and trace element compositions were determined by actalabs (http://www.actalabs.com) or on lithium tetraborate fusion pills using a Rigaku RINT 2000 powder X-ray diffractometer at the Tokyo Institute of Technology. Trace elements of the fusion pills were determined by LA-ICPMS at the University of Bern. Technical details are given in the electronic appendix.

\section{Results}

\section{Geochemistry}

The mineralogy and major element compositions (Table 1 and Fig. 6) classify the granitoid rocks of the Dir/Kalam and Chilas area as I-type, calc-alkaline, diorite-tonalitegranodiorite-granite suite. They are meta-aluminous to slightly per-aluminous (Al-saturation index $(\mathrm{A} / \mathrm{CNK}=$ $\mathrm{Al}_{2} \mathrm{O}_{3} /\left(\mathrm{CaO}+\mathrm{Na}_{2} \mathrm{O}+\mathrm{K}_{2} \mathrm{O}\right)$ in $\left.\left.\mathrm{mol} \%\right)<1.1\right)$ with a variable range in $\mathrm{Al}_{2} \mathrm{O}_{3}(15-20 \mathrm{wt} \%)$. The $\mathrm{SiO}_{2}$ content varies significantly $\left(\mathrm{SiO}_{2}=50.6-75.7 \mathrm{wt} \%\right)$. The primitive mantle-normalized (Sun and McDonough, 1989) trace element patterns (Fig. 7) are generally enriched in light rare earth (LREE) compared to middle (M)REE and heavy (H)REE. Samples from the Dir area, which are from a shallower crustal level, have generally higher trace element concentrations than samples from the Chilas area, which are from a deeper crustal level. Based on the M- and HREE element characteristics, two sample groups are distinguished in the Chilas area: In group 1 the middle to heavy REE are unfractionated whereas in group 2 the HREE are depleted compared to MREE similar to some Archean TTG rocks. A similar grouping is made in the Southern Plutonic Complex (Garrido et al. 2006) and in the northern part of the Kohistan Batholith (Petterson and Windley 1985; Petterson and Windley 1991). In all samples, $\mathrm{Nb}$ and $\mathrm{Ta}$ are depleted compared to $\mathrm{La}$ and $\mathrm{K}$ coupled with a pronounced positive $\mathrm{Pb}$ anomaly, thus confirming the overall subduction-related tectonic environment envisioned for the Kohistan Arc. In some samples, $\mathrm{Ba}, \mathrm{Eu}$, and $\mathrm{Sr}$ are enriched compared to neighboring elements whereas these elements are depleted in other samples, suggesting plagioclase accumulation and fractionation, respectively. Most samples show a negative Ti anomaly but few samples from the Chilas area show a positive Ti anomaly; this duality is interpreted as fractionation and accumulation of Ti-bearing phases, respectively. Positive $\mathrm{Zr}$ and $\mathrm{Hf}$ anomalies characterize samples containing zircon. Additionally, whole rock data of a fine grained amphibolite and an coarse grained metagabbro from the south of the Chilas Complex, both displaying no melting evidence, are presented in Table 1 , along with a granitic leucosome vein and a migmatized metasediment with $\sim 50 \%$ leucosome which come from the same enclave within the Chilas gabbronorite (Fig. 3). The amphibolite 


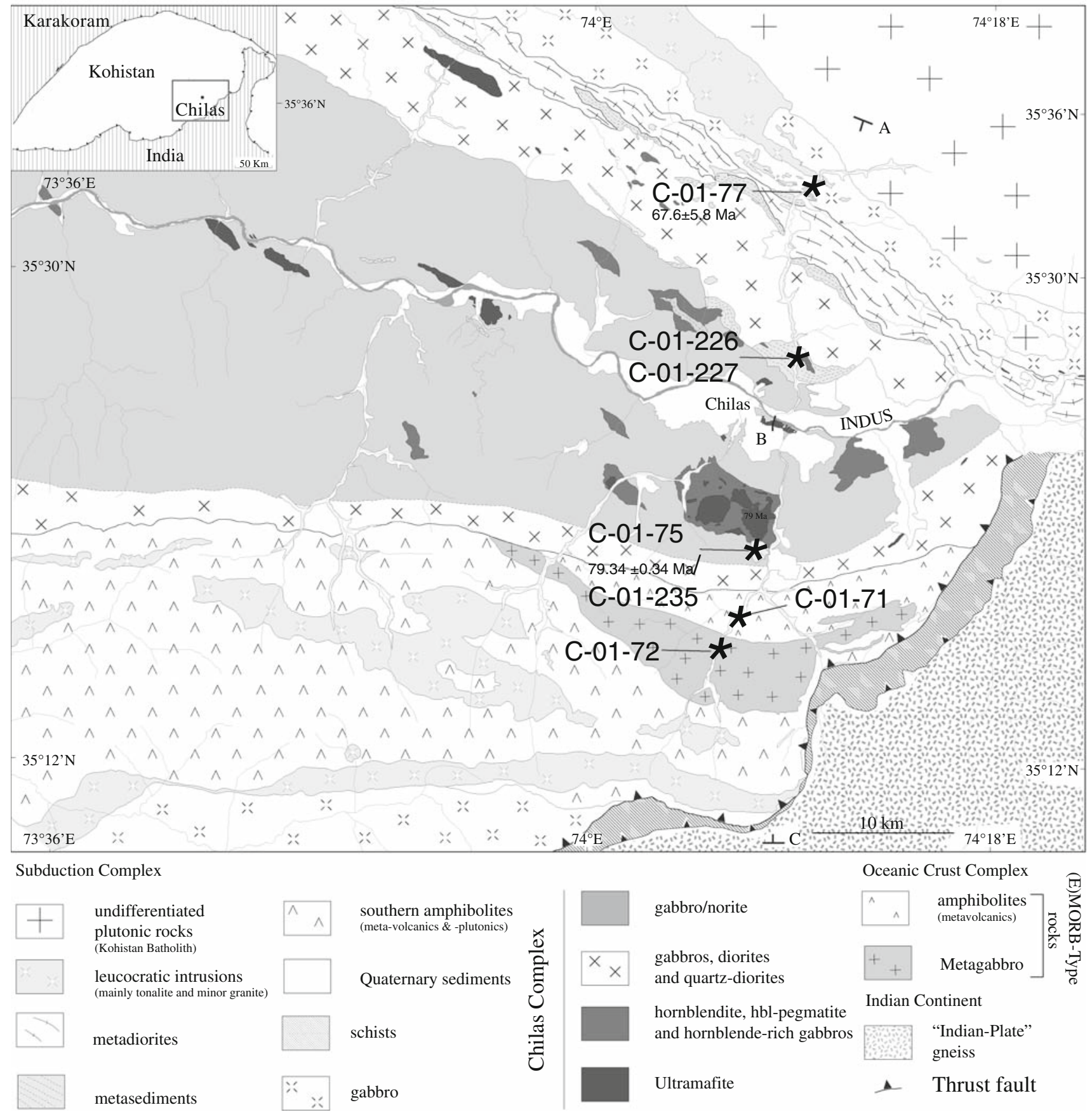

Fig. 3 Geological map of the Chilas area (modified after Jagoutz et al. 2007), location Fig. 1). $A, B$ and $C$ indicate the location of the crosssection presented in Fig. 4. Sample locations are given as stars along with the $\mathrm{U}-\mathrm{Pb}$ zircon ages (in $\mathrm{Ma}$ ) from this study

and the metagabbro have both a basaltic major element composition and an (E)MORB-type whole rock trace element pattern characterized by a flat trace element spectrum and a slight LREE depletion. The metagabbro has low trace element concentration and positive anomaly in $\mathrm{Sr}$ and $\mathrm{Eu}$ indicating plagioclase accumulation. Similar rocks have been described in the same structural position by Khan et al. (1993) and observed by the first author in other parts of the arc (Fig. 1) and are considered to represent remnants of the oceanic crust either on which the Kohistan arc has grown (i.e. the basement) or relicts from a back arc basin.

In the migmatite, where garnet is a common restitic mineral, the HREE are fractionated from L- and MREE (e.g. $\mathrm{La}_{N} / \mathrm{Gd}_{\mathrm{N}} \sim 7-12 ; \mathrm{Gd}_{\mathrm{N}} / \mathrm{Lu}_{\mathrm{N}} \sim 1.5-2$; and $\mathrm{La}_{\mathrm{N}} / \mathrm{Lu}_{\mathrm{N}}$ $\sim 14-19)$ and the incompatible trace elements are enriched (Fig. 7c, d). The granitic leucosome is strongly LREE 


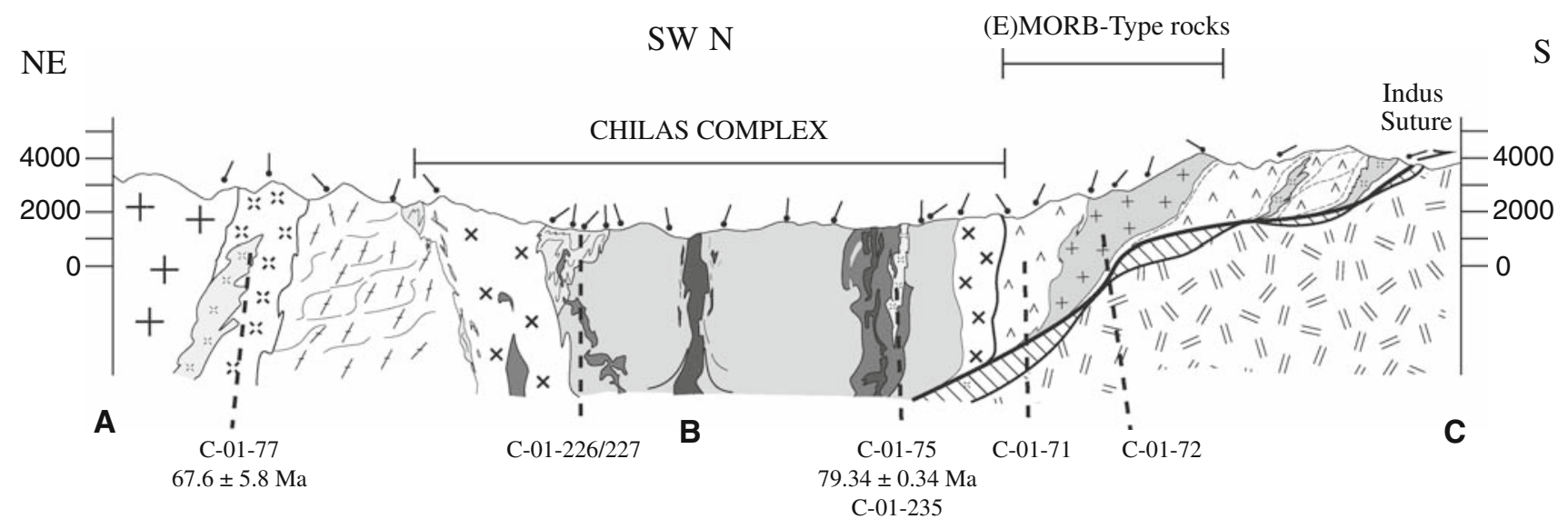

Fig. 4 Geological cross-section through the Chilas Complex and adjoining unit showing the overall structure and relationships between various units. Lithology as in Fig. 3, after (Jagoutz et al. 2007)

enriched and has a fractionated HREE element pattern in accordance with the restitic garnet in the metasediment; in addition, a distinct negative $\mathrm{TiO}_{2}$ anomaly is observed. A major characteristic of partial melts is their strong depletion of $\mathrm{U}$ and $\mathrm{Th}$, which might be due to U-Th-bearing mineral phases (e.g. monazite) in the restite.

\section{Geochronology}

\section{Cathodoluminescence}

In general, the analyzed zircons have a 100-500 $\mu \mathrm{m}$ long, prismatic and pyramidal shape. Inclusions of unidentified opaque minerals are common. Cathodoluminescence from all but two samples show homogeneous patchy to oscillatory magmatic growth patterns with locally thin overgrowth along the rim (Fig. 8a) that yielded same age. Few older zircons from sample C-01-77 show bright secondary patches overgrowing magmatic oscillatory growth pattern (Fig. 8b). These patches indicate minor recrystallization (Pidgeon 1992). However, younger zircons from the same sample show oscillatory magmatic growth patterns.

\section{Zircon chronology}

Results are given in Table 2. Ages are graphically presented in conventional Concordia diagrams and frequency plots (Fig. 9) and integrated to published ages from Kohistan (Fig. 10). The strongly foliated tonalite C-01-77 (Appendix) yields an age of $67.4 \pm 5.8 \mathrm{Ma}$. Colorless 100-200 $\mu \mathrm{m}$ zircons from the undeformed MN-02-04 granite yield an age of 72.3 $\pm 5.1 \mathrm{Ma}$. Sample MR-02-03 was collected from what we had mapped to be part of the same plutonic body as Mn-02-04, about $10 \mathrm{~km}$ to the west (Fig. 5) and yield a statistically indistinguishable age of
$70.3 \pm 5.0 \mathrm{Ma}$. This plutonic body has clear intrusive relationship into Dir-Utror volcanic rocks and accordingly constrains a lower estimate for their eruption age. The undeformed RB-02-16 granite yields an age of $57.3 \pm$ 5.3 Ma. Mapping indicates intrusion of the granite into the surrounding BO-02-13 diorite (Fig. 5) consistently dated at $62.1 \pm 4.9 \mathrm{Ma}$. The BR-02-19 quartz-diorite yields an intrusion age of $75.1 \pm 4.5 \mathrm{Ma}$. The DR-02-18 diorite is dated at $42.1 \pm 3.7 \mathrm{Ma}$.

All samples sporadically show older, inherited zircons. These are generally younger than oldest known Kohistan arc magmatism ( $154 \mathrm{Ma}$, Schaltegger et al. 2004) except for very few inherited zircons which are up to $\sim 220 \mathrm{Ma}$.

\section{Discussion}

\section{Granitoid origin}

Granitoids from the Kohistan Batholith can be classified as magnesian, calcic to calc-alkaline arc rocks. The trace element characteristic (e.g. $\mathrm{Nb}$ and Ta depletion, LILE enrichment) implies a subduction-related origin consistent with the conventional magmato-tectonic interpretation of the Kohistan arc. Positive $\mathrm{Ba}, \mathrm{Sr}$ and $\mathrm{Eu}$ anomalies indicate accumulation of plagioclase and negative ones indicate fractionation of plagioclase. Accordingly, some rocks have clear cumulative characters and some might approach liquid compositions. The granitoides are a typical tonalite, granodiorite and granite suite (Fig. 6a). The characteristics of the Kohistan arc granitoids is similar to that of active oceanic island arc granitoids such as the Aleutian and New Britain plutons (Whalen 1985) and seems to be general to island arc granitoids. Their composition, however, differs from bulk upper crustal compositions, especially in their relatively low incompatible trace element content. 


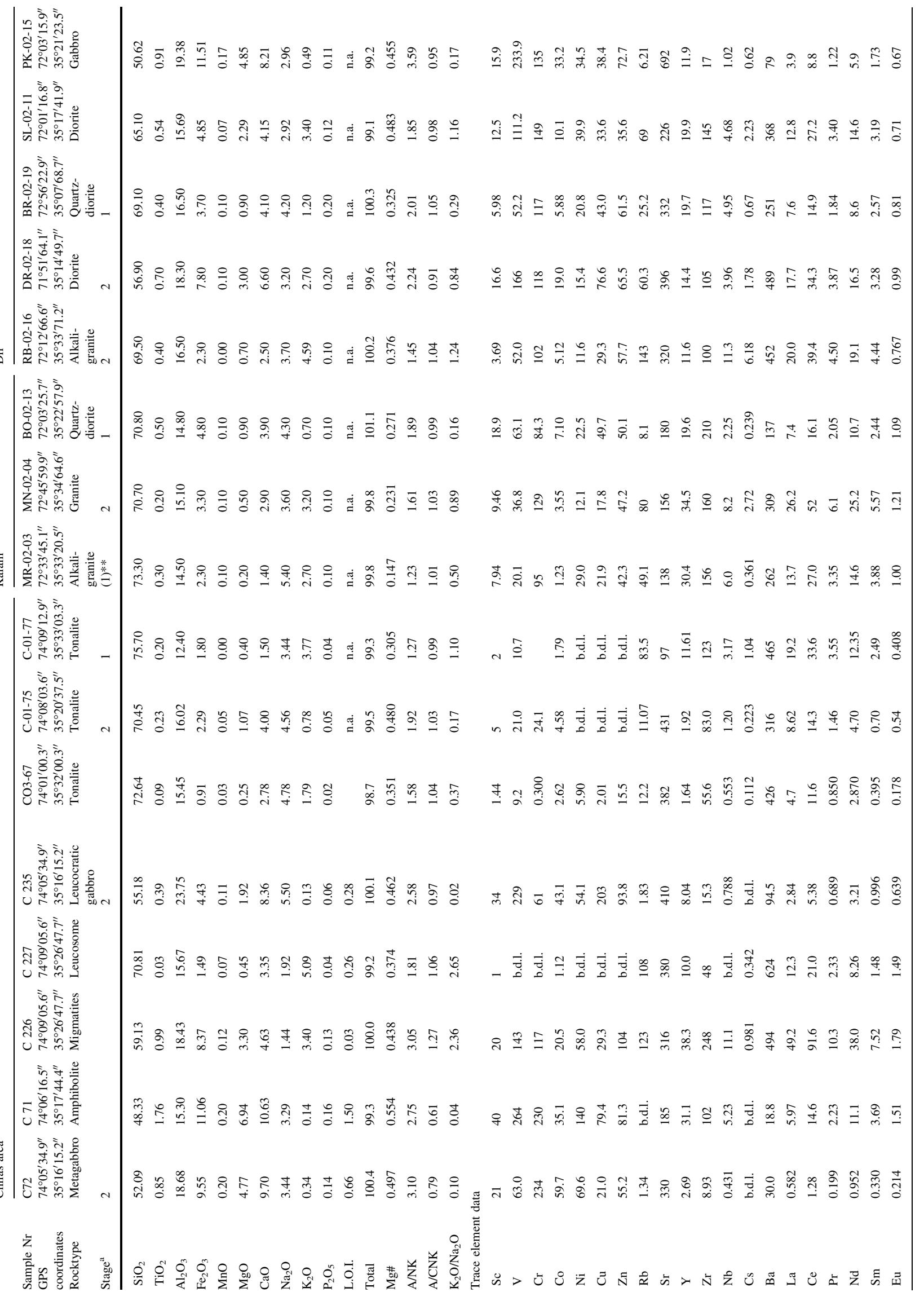




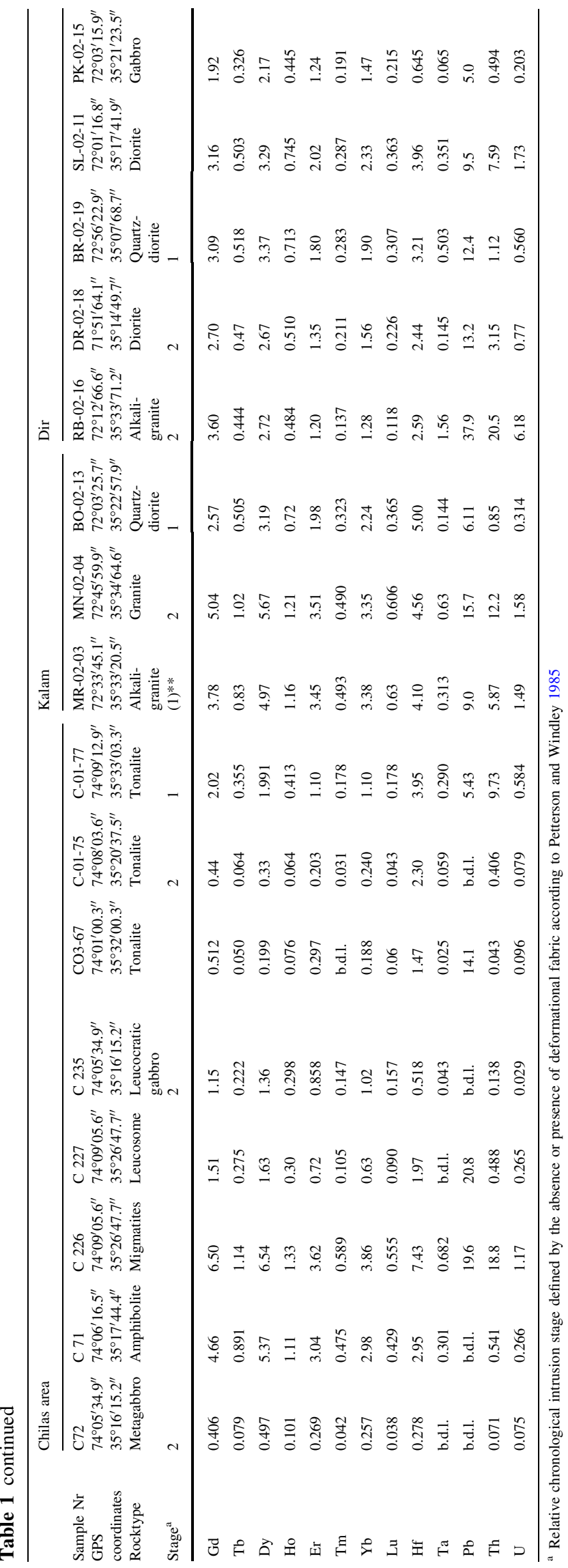


Fig. 5 Simplified geological map of the Dir-Kalam area (location Fig. 1) based on published maps (Jan and Mian 1971; Butt et al. 1980;

Chaudhry et al. 1987) modified after new mapping and interpretation of multispectral Landsat $7 \mathrm{ETM}+$ satellite images. Sample location are given along with the $\mathrm{U}-\mathrm{Pb}$ zircon ages (in Ma) from this study; T-symbols indicate attitudes of foliation planes

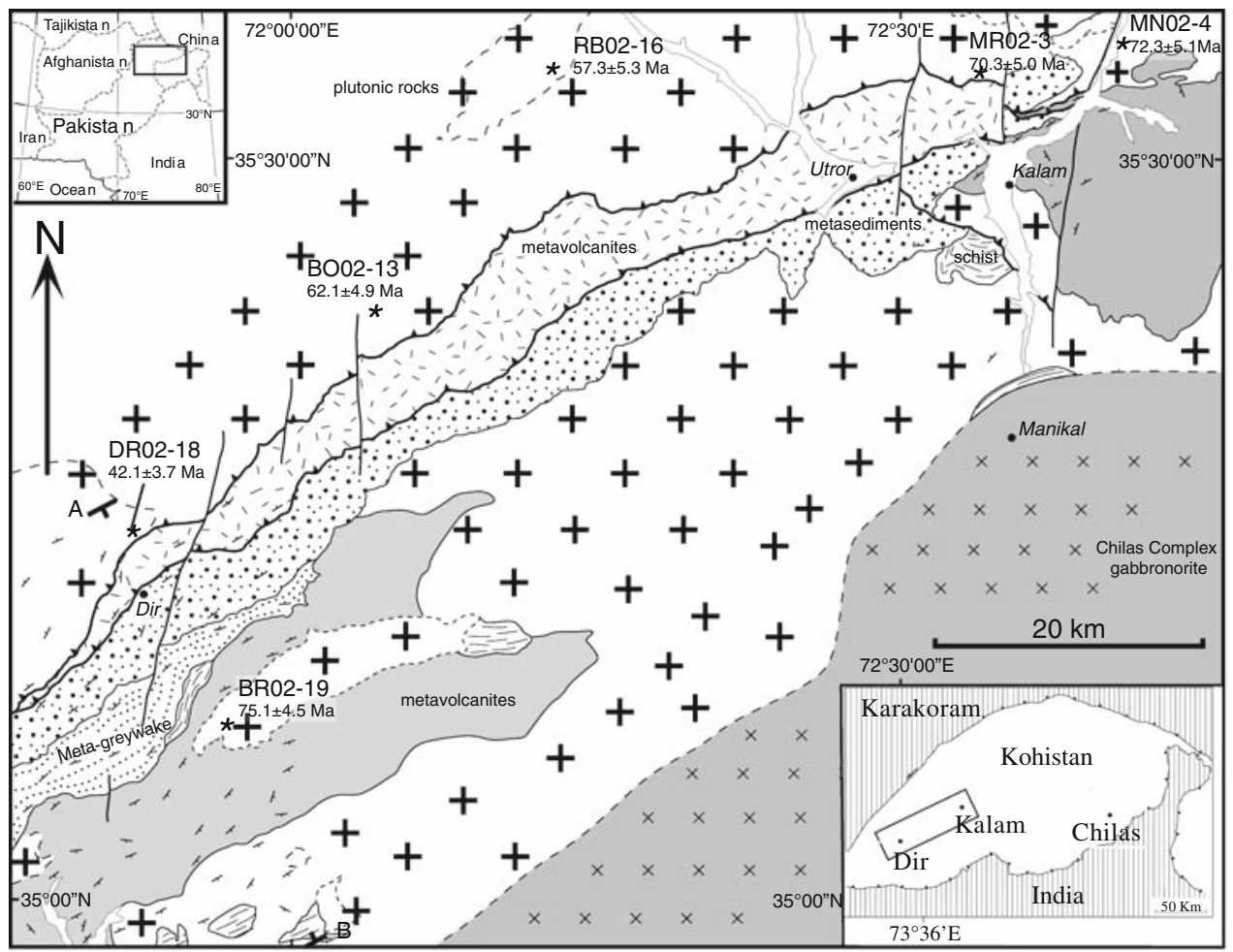

NW

SE

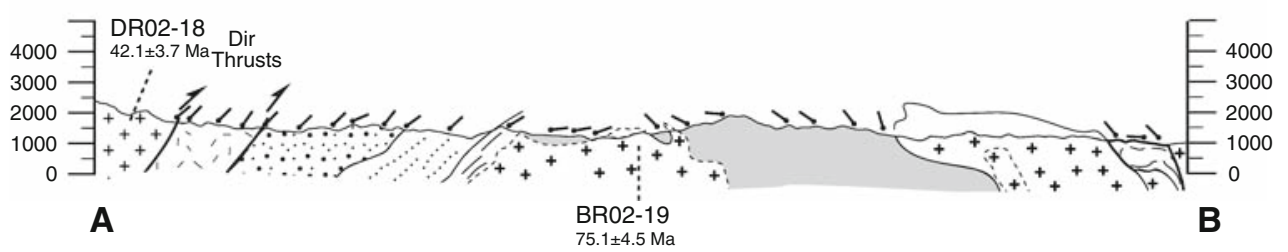

Granitoid formation by partial melting due to the intrusion of the Chilas Complex or by fractional crystallization?

If the Chilas intrusion triggered significant partial melting of the crust, then this event should be recorded as unrepeated increase in intrusion volumes with evidence for migmatisation spatially linked to the Chilas gabbronorite.

This is the case in the western, deeper part of the studied area: to the south, numerous tens-of-centimeter wide, ptygmatitic-folded pegmatitic veins occur in increased frequency and volume in country rocks toward their contact with the gabbronorite. Melting in metasedimentary enclaves within and along the northern contact of the Complex is restricted to more fertile (i.e. higher modal mica content) metapsammitic (metagreywake) rocks but leucocratic veins are volumetrically limited. However, a muscovite and biotite dehydration reaction that occurs at much lower temperature than hornblende dehydration could produce significant amounts of partial melt derived from metasediments. The minimum melts produced by partial melting of metasediments are however compositionally distinct from the Kohistan granitoids: they have significantly lower $\mathrm{Na}_{2} \mathrm{O}$ content and their depletion in $\mathrm{U}$ and $\mathrm{Th}$ conflicts with the high $\mathrm{U}$ concentration in the granitoids (Fig. 7c and Table 1).

Assimilation structures are frequent throughout the Kohistan arc but the importance of that assimilation is difficult to quantify. Isotopic differences between plutons are very subtle and the majority of the granitoids, including leucogranites, have $\mathrm{Sr}_{\text {inital }} \sim 0.7035-0.704$ similar to the range measured in mafic lithologies [(Petterson and Windley 1986), and personal unpublished data]. Furthermore, isotopic ratios generally do not correlate with incompatible trace element concentrations. This observation implies either that intra-crustal assimilation and mixing is negligible or, more likely, that the time elapsed between different magmatic pulses is too short for isotopic systems to evolve so that the isotopic difference between assimilant and assimilating melt is negligible. Therefore, isotopic fingerprints in ocean island arc systems cover too narrow a range to infer intracrustal mixing and assimilation. The presence of inherited zircons 


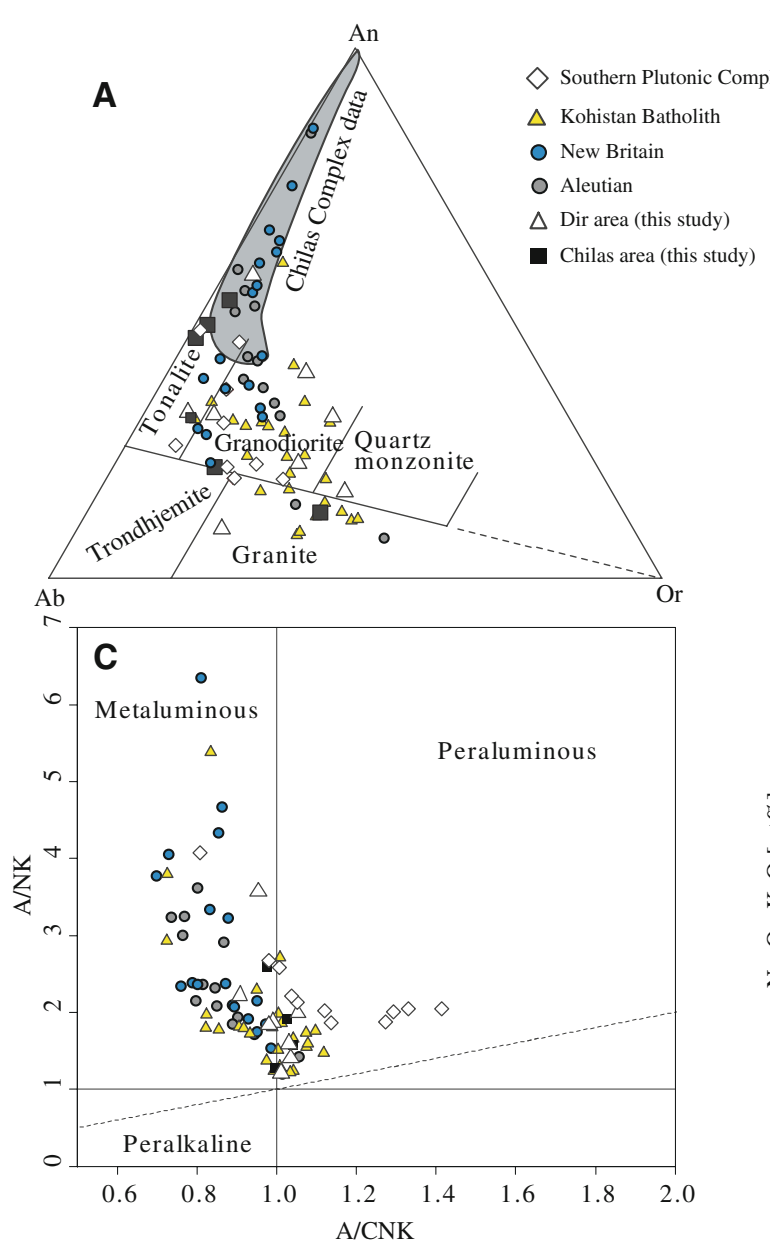

Fig. 6 Whole rock major element composition of the studied granitoid samples. a Feldspar triangle (O'Connor 1965), b AFM diagram (Irvine and Baragar 1971), c A/CNK-A/NK plot (Shand 1943) and d TAS plot (Cox et al. 1979; Wilson 1989). The results of this study are compared to the other granitoid samples from the

with igneous oscillatory growth patterns in nearly all analyzed samples indicates that plutonic rocks were assimilated (Fig. 9). Zircons with different ages in a single sample document assimilation of various wall rock units rather than remelting of a homogenous, aged precursor as proposed for Ladakh granitoids (Weinberg and Dunlap 2000).

Despite evidence for localized melting and assimilation, our new $\mathrm{U}-\mathrm{Pb}$ data preclude intrusion of the Chilas Complex at $85 \mathrm{Ma}$ (Schaltegger et al. 2002) as the source of the younger 42-75 Ma granitoids of the Kohistan Batholith. Together with previously published intrusion ages, our results document that granitoid formation in the Kohistan arc began well before, and extend well after the rifting event that led to the Chilas Complex. The current dataset indicate that grantitoid formation was continuous rather than punctuated process and latest at least from 112 to 38 Ma (Fig. 10).
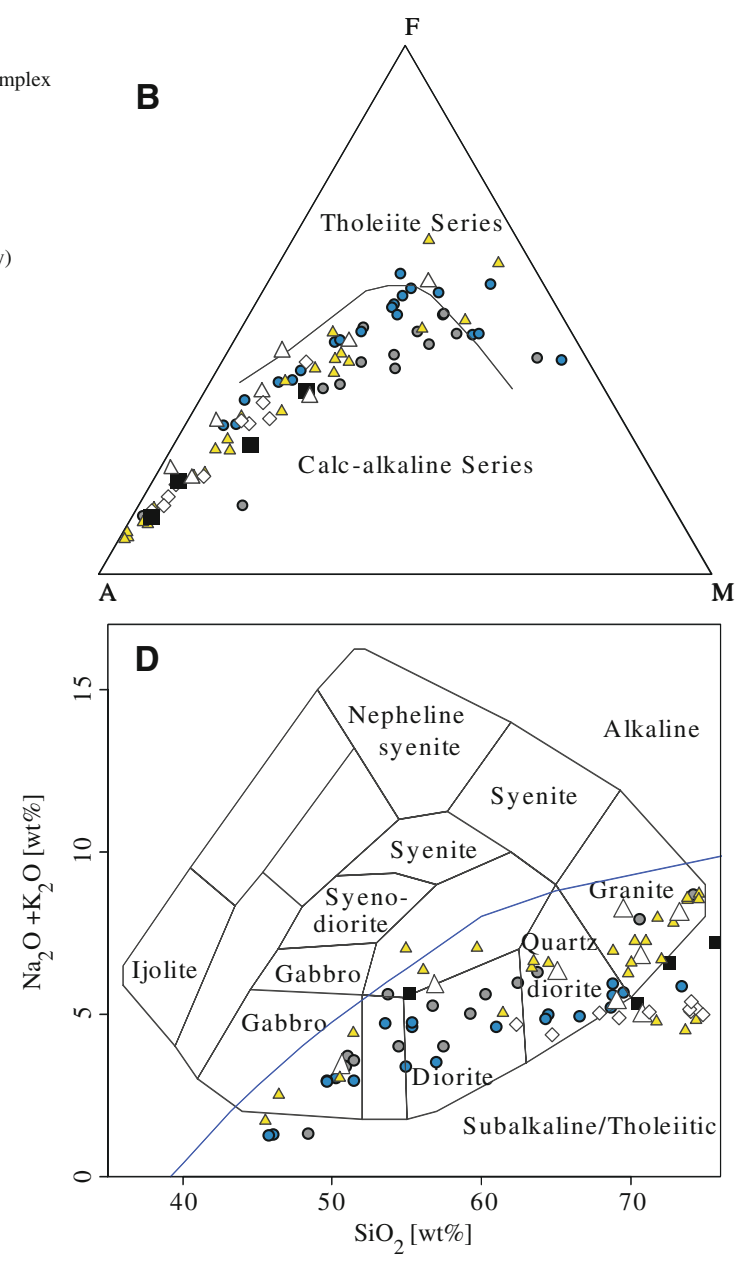

(northern) Kohistan Batholith (Petterson and Windley 1985; Petterson and Windley 1991; Heuberger et al. 2007) and to granitoid samples from the Southern Plutonic Complex (Zeilinger 2002; Garrido et al. 2006). Kohistan granitoids are compared to oceanic arc granitoids from the Aleutian (Perfit et al. 1980) and New Britain (Whalen 1985)

It is difficult to distinguish between steady state partial melting and fractional crystallization from the granitoid composition alone. A significant difference between partial melting and fractionation may be the initial water-content of the protolith and the appearance/disappearance of amphibole in the fractionation/partial melting sequence (Annen et al. 2006): Experiments have shown that dehydration melting of basaltic compositions can engender compositions akin to silica-rich compositions found in arcs (e.g. Beard and Lofgren 1991). However, the initial water content of the protolith cannot exceed the amount of water bound in hydrous mineral phases (e.g. amphibole). This limits the bulk water content of protolithic rocks to $\leq 2 \mathrm{wt} \%$. Experiments on natural rocks indicate that the stability field of amphibole is reduced with decreasing water content. Accordingly, the modal amount of amphibole diminishes during partial melting with increasing 

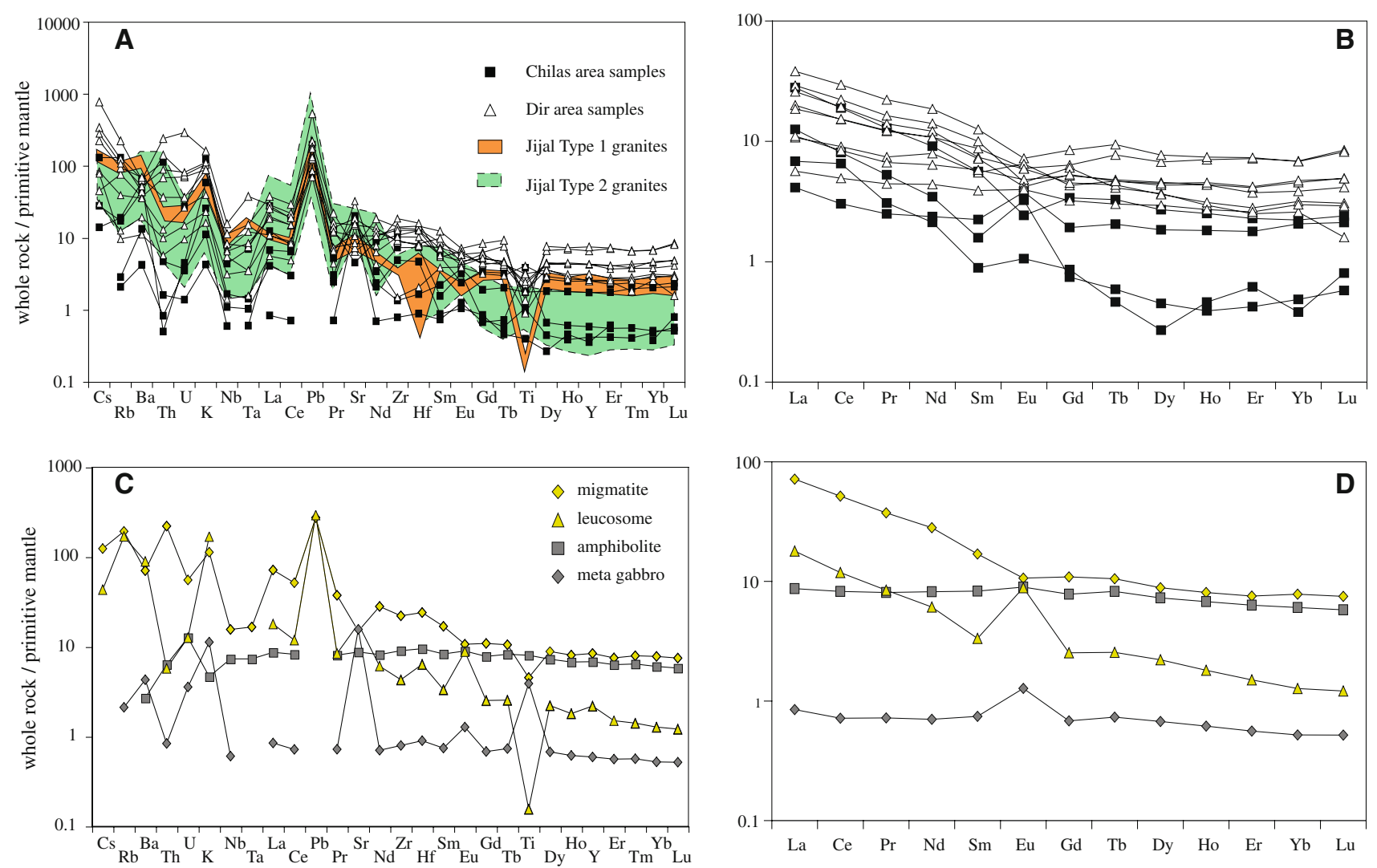

Fig. 7 Primitive Mantle (Sun and McDonough 1989) normalized multi-trace element diagram and rare earth trace element diagram of the studied samples. a, b Trace and REE elements of the plutonic

rocks compared to Typ 1 and 2 granitoids from the Southern Plutonic Complex. c, $\mathbf{d}$ The trace and REE elements of the sedimentary and migmatitic rocks found in the vicinity of the Chilas Complex

Table 2 U-Pb LA-ICPMS zircon analysis from plutonic samples from the Kohistan Batholith of the Kohistan arc

\begin{tabular}{lllllllcc}
\hline Sample Nr & $\begin{array}{l}\text { Number of } \\
\text { zircons averaged }\end{array}$ & ${ }^{206} \mathrm{~Pb} /{ }^{238} \mathrm{U}$ & $( \pm 2 \sigma)$ & ${ }^{207} \mathrm{~Pb} /{ }^{206} \mathrm{U}$ & $( \pm 2 \sigma)$ & ${ }^{207} \mathrm{~Pb} /{ }^{235} \mathrm{U}$ & $\begin{array}{c}( \pm 2 \sigma) \\
\left.{ }_{238} \mathrm{U} /{ }^{206} \mathrm{~Pb}\right)\end{array}$ \\
\hline $\mathrm{C}-01-75$ & & & & & & & $79.34 \pm 0.34^{\mathrm{a}}$ \\
$\mathrm{C}-01-77$ & 60 & 0.0105 & 0.0009 & 0.049 & 0.007 & 0.072 & 0.010 & $67.4 \pm 5.8$ \\
MR-02-03 & 18 & 0.0110 & 0.0008 & 0.055 & 0.014 & 0.083 & 0.020 & $70.3 \pm 5.0$ \\
MN-02-04 & 59 & 0.0113 & 0.0008 & 0.054 & 0.012 & 0.084 & 0.019 \\
BO-02-13 & 27 & 0.0097 & 0.0008 & 0.050 & 0.012 & 0.067 & 0.016 & $62.1 \pm 4.9$ \\
RB-02-16 & 40 & 0.0089 & 0.0008 & 0.050 & 0.007 & 0.062 & 0.011 & $57.3 \pm 5.3$ \\
DR-02-18 & 60 & 0.0066 & 0.0007 & 0.052 & 0.016 & 0.047 & 0.015 & $42.1 \pm 3.7$ \\
BR-02-19 & 20 & 0.0117 & 0.0008 & 0.048 & 0.010 & 0.077 & 0.017 & $75.1 \pm 4.5$ \\
\hline
\end{tabular}

${ }^{\text {a }}$ Own unpublished U-Pb (TIMS) age on Zircon

degree of partial melting i.e. with decreasing $\mathrm{SiO}_{2}$ of the partial melts. Amphibole is generally consumed after few degrees of partial melting (6-15 vol\%, Beard and Lofgren 1991; Rapp et al. 1991) in experiments relevant to compositions found in Kohistan.

In fractional crystallization, the water saturation at a given pressure gives the maximum amount of initial water in parental melt. Water-saturated melts can contain $>14$ vol\% $\mathrm{H}_{2} \mathrm{O}$ (Grove et al. 2003) at pressures corresponding to the lower crust of island arcs $(0.8-1.5 \mathrm{GPa})$. Available data document that primitive arc magmas might not be water-saturated but may have high initial water content ( $\sim 10 \mathrm{wt} \%$, Grove et al. 2002; Grove et al. 2003). In hydrous magmas amphibole can occur relatively early in the fractionation sequence (i.e. before the onset of plagioclase fractionation). Accordingly, existing experimental data supportively indicate that the role of amphibole fractionation occurs over a longer fractional interval during 


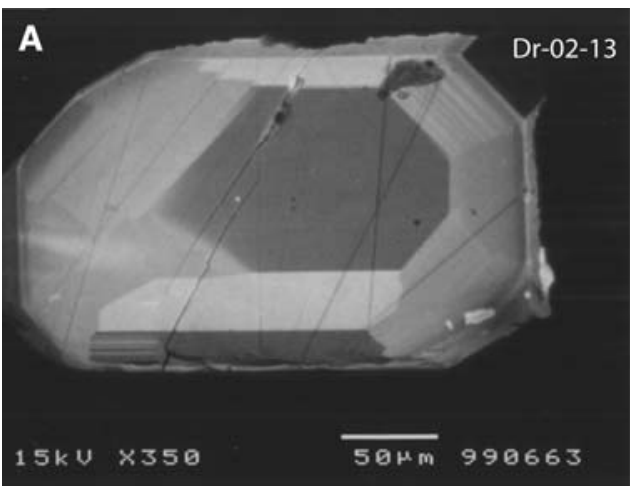

Fig. 8 Cathodoluminiscence images of representative zircons. Zircons from sample Dr-02-13 have darker core and lighter rims (a). The rim is segmented, showing an oscillatory magmatic growth pattern. No detectable age difference exists between core and rim. A similar

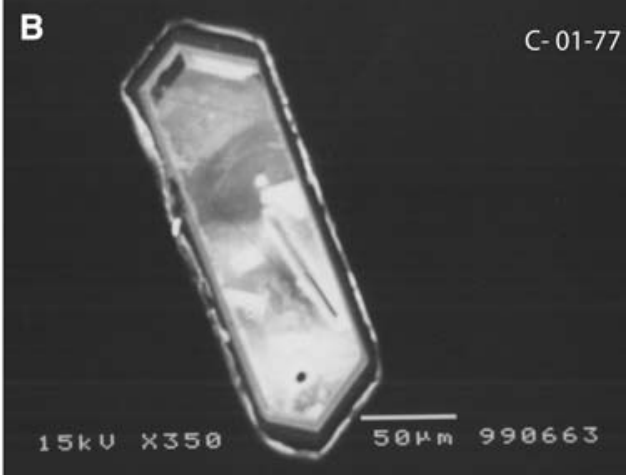

magmatic growth pattern is generally observed in other analyzed samples except those presented in (b). Some zircons from sample C01-77 show signs of recrystallisation whereas others show homogenous magmatic growth pattern
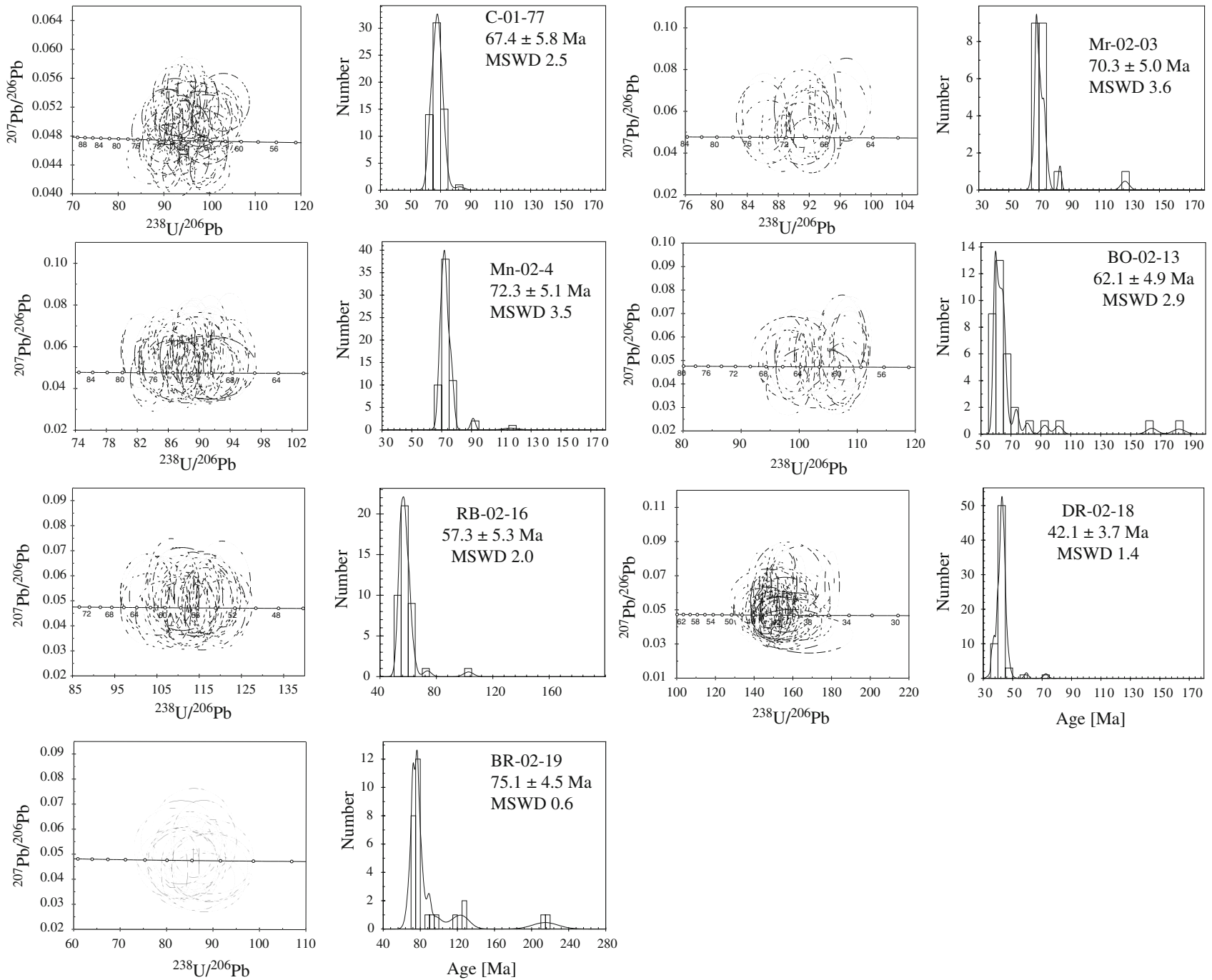
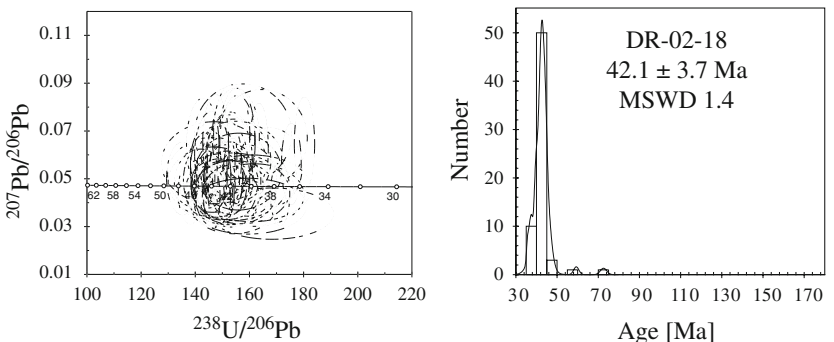

Fig. 9 Conventional concordia plots and frequency histograms of the analyzed zircons. Ages are calculated using the ${ }^{206} \mathrm{~Pb} /{ }^{238} \mathrm{U}$ ratios and errors of individual analyses (size of ellipses) are given as $2 \sigma$. Plots are produced using Ken Ludwig's Isoplot program (Ludwig 2000) 


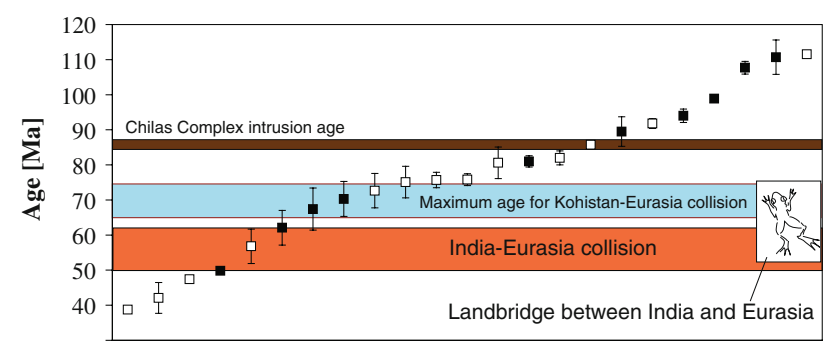

Fig. $10 \mathrm{U}-\mathrm{Pb}$ zircons ages from the Kohsitan arc (data source: this study and Schaltegger et al. 2002; Yamamoto et al. 2005; Heuberger et al. 2007). Available ages document a continuous magmatic history within the Kohistan arc from at least $\sim 120$ to $38 \mathrm{Ma}$. Granitoid formation is temporally unrelated to the intrusion of the Chilas Complex or inferred tectonic events. The maximum age range for the Kohistan-Eurasia collision is based on sedimentological evidence from the neighboring Dras arc (Clift et al. 2000) and constrains for the India-Eurasia collision (Jaeger et al. 1989; Burg 2006). Open symbols indicate undeformed rocks (stage $2 \& 3$ ) and filled symbols are foliated "stage 1" plutons. As is evident form the data, no correlation exists between deformation and intrusion age

fractional crystallization than during partial melting processes.

The general silica enrichment observed in the Kohistan granitoids is associated with decreasing $\mathrm{TiO}_{2}$ content and a roughly $8-10$ fold increase in $\mathrm{Zr} / \mathrm{Sm}$ with a significant increase in silica content (Fig. 11) indicating fractionation of low $\mathrm{Si}$, high $\mathrm{Ti}$ phases such as $\mathrm{Fe}-\mathrm{Ti}$ oxide and/or amphibole. This implies that amphibole was present in the fractionation sequence over a significant interval, which additionally favors fractional crystallization over partial melting processes. Even if amphibole is often absent in volcanic arc rocks, it is common in plutonic xenoliths from various subduction zones (Arculus and Wills 1980). Indeed, magmatic amphibole is present throughout the lower part of the arc: In the upper part of the Jijal mantle section amphibole becomes up section increasingly abundant and pyroxene-rich ultramafic rocks grade into hornblende-, clinopyroxene- and garnet-rich rocks. Modal variations are pronounced and rock-types vary from hornblendite to garnetite and pyroxenite within centimeter to outcrop scales. These modal variations occur as confined bands/dykes or as diffuse schlieren whereas the transition between both occurrences takes place over few centimeters. The replacive relationship between pyroxene-rich ultramafite and dunite and the irregular transition from schlieren to dyke-shaped garnetite and hornblendite are indicating numerous percolative intrusive events and associated melt-rock reactions within a semi-consolidated crystal mush rather than partial melting. Amphibole is present as a magmatic phase in the lower crustal garnet gabbros (Ringuette et al. 1999) and in abundant up to hundred meters sized hornblendite bodies occurring throughout the lower crust (Burg et al. 2005). Contact relationships indicate the presence of older enclaves and younger dikes indicative of multiple magmatic events.

It has been proposed that the lower part of the Jijal Complex is related to partial melting. Garrido et al. (2006) proposed that widespread partial melting of amphibolebearing two-pyroxene gabbro occurred in the lower crust of the Southern Plutonic Complex and formed garnet-bearing granulite restites. This interpretation is based on scanty field evidence and the equivalence between the metamorphic age of the garnet granulites and the plutonic age of a granite dyke (Garrido et al. 2006). In the light of the results presented here, we contend that this equivalence is fortuitous. However, we concur with Garrido et al. (2006) that field relationships locally observed in the lower crust of the Kohistan arc (i.e. in one outcrop) can be explained by metamorphic reactions, possibly involving partial melt. Garrido et al. (2006) extrapolate these observations to the entire lower part of the arc, which conflicts with the presence of magmatic amphibole in the "garnet granulites" (Ringuette et al. 1999) and with age relationships observed in the field. Apparent "protholiths" (i.e. the so-called Sarangar gabbro and hornblendite bodies) are likely younger and intrude the apparent "restite" (Arbaret et al. 2000; Burg et al. 2005).

Additionally, the garnet- and amphibole-bearing granulites, the proposed restites after partial melting, are char-

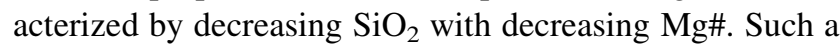
trend is readily explained through cumulative processes during fractional crystallization due to the accumulation of garnet and amphibole, but is difficult to obtain by partial melting (Fig. 11). If partial melting was the dominant rockforming mechanism, then restites became silica-richer with

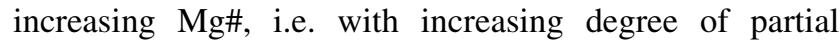
melting. Such a correlation is expected to be mirrored in the expelled fluids. Granitoids, however, generally display a continuous negative correlation between $\mathrm{Mg \#}$ and $\mathrm{SiO}_{2}$. Additionally, some granitoids have high $\mathrm{Ni}$ content (up to $50 \mathrm{ppm}$ ) implying unrealistic high degree of partial meting ( $\sim 100 \%)$. These discrepancies strongly argue for fractional crystallization of a mantle-derived melt as dominant granitoid-forming mechanism.

Therefore, we conclude that field information coupled with major and trace element data is consistent with amphibole dominated hydrous fractional crystallization as the main crust forming process for arc granitoids in Kohistan arc. An often-cited argument against such an interpretation is the minor volume of evolved melts produced by fractional crystallization which are considered insufficient volumes to produce the upper crust which is $30 \%$ of the total continental crust (Rudnick and Gao 2003). This mass balance deficiency is apparent if Si-enrichment is due to "gabbro" fractionation (i.e. olivine, pyroxene, and plagioclase). In such a liquid line of decent the high $\mathrm{SiO}_{2}$ content (52-54 wt $\%$ ) of early fractionating plagioclase and 


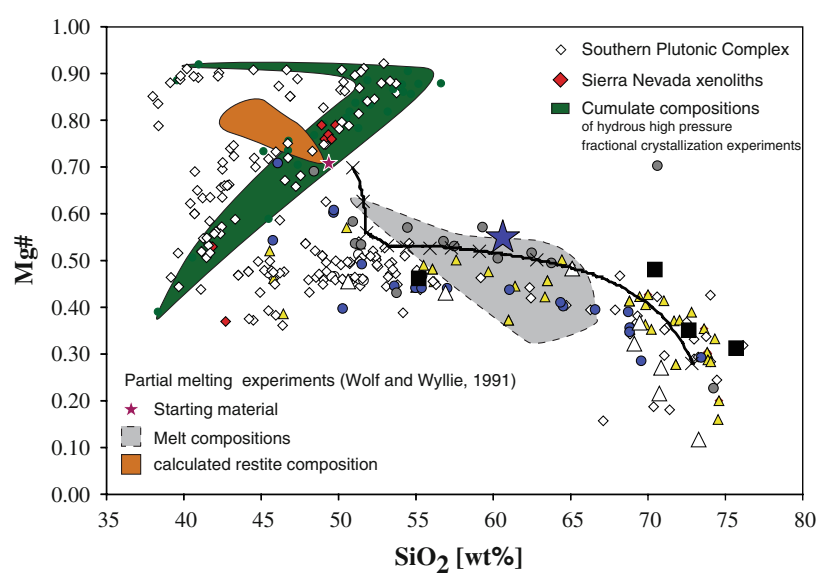

Fig. 11 a Variation in $\mathrm{SiO}_{2}$ versus $\mathrm{Mg} \#$ in whole rock arc granitoids and ultramafic to granitoid rocks from the Southern Plutonic Complex (data source: own unpublished data and Jan and Howie 1981; Zeilinger 2002; Garrido et al. 2006; Dhuime et al. 2007), and deep crustal xenoliths from Sierra Nevada (Lee et al. 2006). Natural data is compared to the trend of calculated cumulate compositions from mineral composition and modal abundance of hydrous high pressure fractional crystallization experiments (Alonso-Perez et al. 2009), and to the trend of the melt and calculated restite composition of partial melting experiments (Wolf and Wyllie 1991). Evidently natural data

(clino-)pyroxene inhibits volumetrically significant silica enrichment. Alternatively, much larger volumes of Si-rich rocks can be formed by liquid lines of decent that evolve through hydrous higher-pressure fractional crystallization. The plagioclase stability field under hydrous conditions and higher pressure is reduced compared to that of Si-poor minerals such as amphibole (medium pressure) and garnet (higher pressure). Fractionation of these mineral phases pushes derivative liquids to silica-rich compositions over a short fractionation interval (Müntener et al. 2001; AlonsoPerez et al. 2009). In an accompanying paper (Jagoutz 2009) a quantitative petrogenetic model for the formation of the Kohistan arc granitoids by a combination of fractionation and assimilation is presented.

\section{Regional implication of the geochronological data}

The relative and absolute geochronology of the Kohistan Batholith has strong influence on the geodynamic interpretation of the Kohistan arc (Petterson and Windley 1985, 1986; Petterson and Windley 1986; Treloar et al. 1996). Particularly important is its conversion from an intra-oceanic Kohistan island arc to an active margin welded to the continent after collision with Eurasia (Karakoram), to the north. Based on the assumption that solid state fabric must result from regional deformation, suturing between the Kohistan Arc and the Karakoram continental active margin

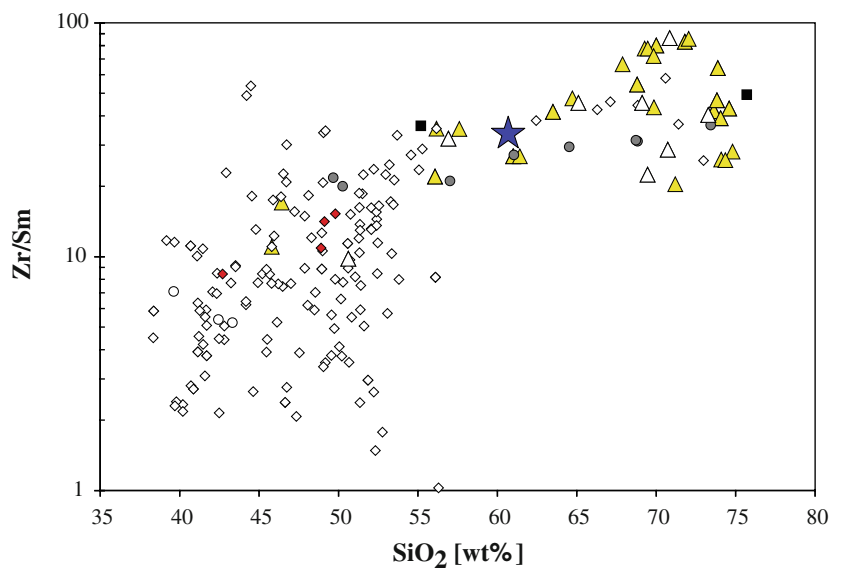

is in better accordance with the fractional crystallization experiments. The black line is the composition trend derived from a fractional crystallization model calculated using actual cumulate compositions from the Kohistan arc (Jagoutz 2009). Symbols as indicated or as given in Fig. 6. b Variation in $\mathrm{Zr} / \mathrm{Sm}$ versus $\mathrm{SiO}_{2}$ for arc granitoids. A continuous increase in $\mathrm{Zr} / \mathrm{Sm}$ is observed with increasing $\mathrm{SiO}_{2}$ concentration, which can be related to amphibole fractionation (Thirlwall et al. 1994). The spread in $\mathrm{Zr} / \mathrm{Sm}$ observed for rocks with high $\mathrm{SiO}_{2}$ concentrations is related to the fractionation and accumulation of Zircon

was inferred to have occurred between the age of deformed stage 1 plutons and the age of undeformed stage 2 plutons (Chilas Complex), i.e. between 104 and 85 Ma (Treloar et al. 1996) (Fig. 10). With this interpretation, the protoliths of stage 1 plutons would have intruded during the intra-oceanic stage of the Kohistan arc. The undeformed stage 2 plutons would have intruded into the new Andeantype margin of Eurasia in the Late Cretaceous. Treloar et al. (1996) noted that the geochronological information contains a gap from 104 to $85 \mathrm{Ma}$ and from 75 to $55 \mathrm{Ma}$, which they interpreted as time-depending and iterative magmatic activity responding to alternating extension and compression in the Kohistan arc.

New ages presented here do not support these assumptions. No significant age difference exists between deformed (presumed stage 1; BR-02-19: $75.1 \pm 4.5 \mathrm{Ma}$; C-01-77: $67.4 \pm 5.8 \mathrm{Ma}$ and BO-02-13: $62.1 \pm 4.9 \mathrm{Ma}$ ) and undeformed (stage 2; MN-02-04: $72.3 \pm 5.1 \mathrm{Ma}$; RB02-16: $57.3 \pm 5.3 \mathrm{Ma}$; DR-02-18: $42.1 \pm 3.7 \mathrm{Ma}$ ) plutons of the Dir-Kalam region (Fig. 10). All analyzed samples are younger than the apparent stage 2 Chilas gabbronorite $(85.73+0.15 \mathrm{Ma}$ Schaltegger et al. 2002). The discrepancy with previous interpretations is further supported by the precise intrusion age of a $49.80 \pm 0.15$ Ma metagabbro, which presents an intense fabric, hence all visual characteristics of a stage 1 intrusion (Heuberger et al. 2007). The assumptions (Petterson and Windley 1985, 1986; Treloar et al. 1996) omitted the fact that plutonism does involve 
solid state strain (e.g. Paterson Scott et al. 1989; Pons et al. 1992). In that case, solid state, crystal plasticity features (e.g. tapered plagioclase twins and quartz grains with undulose extinction) may be heterochroneous. Knowing that protracted plutonism formed the Kohistan Batholith, regionally heterochroneous deformation would reconcile structural and geochronological information. Indeed, in most regions of the Kohistan Batholith that we have studied, like in the Dir area, we observed that strain is heterogeneously distributed and that magmatic foliations within plutonic rocks are in continuity with main foliations in the country, often hornfelsed rocks. Folds in the area have complex trends concordant with plutonic margins and lineations are usually plunging steeply. Such features are essentially related to magmatic emplacement of imbricate and nested intrusions during the build up of the island arc. An important consequence is that the age and structural difference between supposedly stage 1 and stage 2 plutons is no robust basis to date accretion of Kohistan against Asia. This interpretation is consistent with paleomagnetic data indicating that the Kohistan arc collided with the Indian continent prior to the collision with Asia (Khan et al. 2008). In this geodynamic model the Kohistan arc remained and intraoceanic arc through most of its history.

\section{Conclusion}

$\mathrm{U}-\mathrm{Pb}$ zircon ages document that a steady state process produced the Kohistan granitoids. Older inherited zircons are observed in most samples indicating the importance of assimilation. We argued that field, petrological and geochemical data are consistent with fractional crystallization of mantle-derived melts being the dominant crust-forming process. We conclude that upper continental crust is formed in intra oceanic subduction zones by high(er) pressure fractional crystallization of hydrous mantle derived melts. The similarities of granitoids found in the Kohistan arc with some Archaean TTG gneisses imply that comparable mechanisms can explain the major element chemistry of Archaean upper crust. Our results do not support the proposed relative geochronology of Kohistan granitoids, and therefore question the generally accepted view that Kohistan collided with Asia prior to India.

Acknowledgments The Swiss National Science Foundation supported OJ's and JPB's work (grants NF 20-49372.96 and NF 20$61465.00)$. OJ thanks the hospitality of the Tokyo Institute of Technology for support during an extended visit supported by Tokyo Tech Award of ETH Zurich. Discussion with Othmar Müntener, Matt Rioux and Tim Grove are highly appreciated. Extremely helpful, detailed reviews by Tom Sisson and an anonymous reviewer greatly clarified and improved the paper.

\section{References}

Alonso-Perez R, Müntener O, Ulmer P (2009) Igneous garnet and amphibole fractionation in the roots of island arcs: experimental constraints on $\mathrm{H}_{2} \mathrm{O}$ undersaturated andesitic liquids: Contrib Mineral Petrol 157:541-558

Annen C, Blundy JD, Sparks RSJ (2006) The genesis of intermediate and silicic magmas in deep crustal hot zones. J Petrol 47(3):505539

Arbaret L (2000) Pre-collisional anastomosing shear zones in the Kohistan Arc, NW Pakistan. In: Khan MA, Treloar Peter J, Searle Michael P, Jan MQ (eds) Tectonics of the Nanga Parbat syntaxis and the western Himalaya. Geological Society of London, London

Arculus RJ, Wills KJA (1980) The petrology of plutonic blocks and inclusions from the Lesser Antilles island arc. J Petrol 21(4):743-799

Baker PE (1968) Comparative volcanology and petrology of the Atlantic island arcs. Bull Volcanol 32:189-206

Bard JP (1983) Metamorphism of an obducted island arc: example of the Kohistan Sequence (Pakistan) in the Himalayan collided range. Earth Planet Sci Lett 65(1):133-144

Beard JS, Lofgren GE (1991) Dehydration melting and watersaturated melting of basaltic and andesitic greenstones and amphibolites at 1, 3, and $6.9 \mathrm{~kb}$. J Petrol 32(2):365-401

Bignold SM, Treloar PJ (2003) Northward subduction of the Indian Plate beneath the Kohistan island arc, Pakistan Himalaya: new evidence from isotopic data. J Geol Soc 160:377-384

Bowen NL (1928) The evolution of the igneous rocks. Dover Publications, Inc., New York

Burg JP (2005) Shear strain localization from the upper mantle to the middle crust of the Kohistan Arc (Pakistan). In: Bruhn D, Burlini L (eds) High-strain zones: structure and physical properties. Special Publications. Geological Society, London, pp 25-38

Burg JP (2006) Two orogenic systems and a transform-transfer fault in the Himalayas: evidence and consequences. Earth Sci Front 13(4):27-46

Burg JP, Jagoutz O, Hamid D, Hussain S (2006) Pre-collision tilt of crustal blocks in rifted island arcs: structural evidence from the Kohistan Arc. Tectonics 25(5):13. doi:10.1029/2005TC001835

Butt KA, Chaudry MN, Ashraf M (1980) An interpretation of petrotectonic assemblage west of W. Himalayan syntaxis in Dir district and adjoining areas, Northern Pakistan. Geol Bull Univ Peshawar 13:79-86

Chaudhry MN, Hussain MS, Quamae N (1987) Geology and Petrography of Barwal-Dir_Bibor area (Toposheet No. 38M/ 16) Dir district, NWF Pakistan. Geol Bull Univ Punjab 22:143152

Clift PD et al (2000) Sedimentary and geochemical evolution of the Dras forearc basin, Indus Suture, Ladakh Himalaya, India. Geol Soc Am Bull 112(3):450-466

Coward MP, Butler RWH, Asif KM, Knipe RJ (1987) The tectonic history of Kohistan and its implications for Himalayan structure. J Geol Soc London 144(3):377-391

Cox KG, Bell JD, Pankhurst RJ (1979) The interpretation of igneous rocks. Allen and Unwin, London, p 450

DeBari SM, Sleep NH (1991) High-Mg, low-Al bulk composition of the Talkeetna island arc, Alaska; implications for primary magmas and the nature of arc crust. Geol Soc Am Bull 103(1):37-47

Dhuime B et al (2007) Multistage evolution of the Jijal ultramaficmafic complex (Kohistan, N Pakistan): implications for building the roots of island arcs. Earth Planet Sci Lett. doi:10.1016/j.epsl. 2007.06.026 
Dufek J, Bergantz GW (2005) Lower crustal magma genesis and preservation: a stochastic framework for the evaluation of the basalt-crust interaction. J Petrol 46(11):2167-2195

Garrido CJ et al (2006) Petrogenesis of mafic garnet granulite in the lower crust of the Kohistan paleo-arc complex (northern Pakistan); implications for intra-crustal differentiation of island arcs and generation of continental crust. J Petrol 47(10):18731914

Green T (1972) Crystallization of calc-alkaline andesite under controlled high pressure hydrous conditions. Contrib Mineral Petrol 34:150-166

Green T (1992) Experimental phase equilibrium studies of garnet bearing I-type volcanics and high-level intrusives from Northland, New Zealand. Trans R Soc Edinburgh Earth Sci 83:429_ 438

Green T, Ringwood AE (1968) Origin of garnet phenocrysts in calcalkaline rocks. Contrib Mineral Petrol 18:163-174

Grove TL, Parman SW, Bowring SA, Price RC, Baker MB (2002) The role of an $\mathrm{H}_{2} \mathrm{O}$-rich fluid component in the generation of primitive basaltic andesites and andesites from the Mt. Shasta region, N California. Contrib Mineral Petrol 142(4):375-396

Grove TL et al (2003) Fractional crystallization and mantle-melting controls on calc-alkaline differentiation trends. Contrib Mineral Petrol 145(5):515-533

Heuberger $S$ et al (2007) Age and isotopic constraints on magmatism along the Karakoram-Kohistan Suture Zone, NW Pakistan: Evidence for subduction and continued convergence after IndiaAsia collision. Swiss J Geosci 24. doi:10.1007/s00015-0071203-7

Holbrook WS, Lizarralde D, McGeary S, Bangs N, Diebold J (1999) Structure and composition of the Aleutian island arc and implications for continental crustal growth. Geology 27(1):3134

Iizuka T, Hirata T (2004) Simultaneous determinations of U-Pb age and REE abundances for zircons using ArF excimer laser ablation-ICPMS. Geochem J 38(3):229-241

Irvine GJ, Baragar WR (1971) A guide to the chemical classification of common volcanic rocks. Can J Earth Sci 8:523-548

Jaeger JJ, Courtillot V, Tapponnier P (1989) Paleontological view of the ages of the Deccan Traps, the cretaceous/tertiary boundary, and the India-Asia collision. Geology (Boulder) 17(4):316-319

Jagoutz O (2009) Construction of the granitoid crust of an island arc part II: a quantitative petrogenetic model. Contrib Mineral Petrol (submitted)

Jagoutz O, Müntener O, Burg J-P, Ulmer P, Jagoutz E (2006) Lower continental crust formation through focused flow in km-scale melt conduits: the zoned ultramafic bodies of the Chilas Complex in the Kohistan Island arc (NW Pakistan). Earth Planet Sci Lett 242(3-4):320-342

Jagoutz O, Müntener O, Ulmer P, Burg J-P, Pettke T (2007) Petrology and mineral chemistry of lower crustal intrusions: the chilas complex, Kohistan (NW Pakistan). J Petrol 48(10):1895-1953

Jan MQ, Howie RA (1981) The mineralogy and geochemistry of the metamorphosed basic and ultrabasic rocks of the Jijal Complex, Kohistan, NW Pakistan. J Petrol 22(1):85-126

Jan QM, Mian I (1971) Preliminary geology and petrography of Swat Kohistan. Geol Bull Univ Peshawar 6:1-32

Jull M, Kelemen PB (2001) On the conditions for lower crustal convective instability. Journal of Geophysical Research, B. Solid Earth Planets 106(4):6423-6446

Kemp AIS et al (2007) Magmatic and crustal differentiation history of granitic rocks from $\mathrm{Hf}-\mathrm{O}$ isotopes in zircon. Science 315(5814):980-983

Khan MA, Jan MQ, Windley BF, Tarney J, Thirlwall MF et al (1989) The Chilas mafic-ultramafic igneous complex; the root of the Kohistan island arc in the Himalaya of northern Pakistan.
In: Malinconico Lawrence L Jr, Lillie Robert J (eds) Tectonics of the western Himalayas. Special Paper: Geological Society of America. Geological Society of America (GSA), Boulder, pp 75-94

Khan MA, Jan MQ, Weaver BL (1993) Evolution of the lower arc crust in Kohistan, N. Pakistan; temporal arc magmatism through early, mature and intra-arc rift stages. In: Treloar PJ, Searle MP (eds) Himalayan tectonics. Geological Society Special Publications. Geological Society of London, London, pp 123-138

Khan SD, Walker DJ, Hall SA, Burke KC, Shah MT, Stockli L (2008) Did Kohistan-Ladakh island arc collide first with India? Geol Soc Am Bull 121(3-4):366-384

Lee C-TA, Cheng X, Horodyskyj U (2006) The development and refinement of continental arcs by primary basaltic magmatism, garnet pyroxenite accumulation, basaltic recharge and delamination: insights from the Sierra Nevada. Contrib Mineral Petrol 151:222-242

Ludwig KR (2000) Isoplot/Ex version 2.4. A geochronological toolkit for Microsoft Excel. Berkeley Geochronological Centre Special Publication, p 56

Müntener O, Kelemen PB, Grove TL (2001) The role of H2O during crystallization of primitive arc magmas under uppermost mantle conditions and genesis of igneous pyroxenites; an experimental study. Contrib Mineral Petrol 141(6):643-658

O'Connor J (1965) A classification for quartz-rich igneous rocks based on feldspar ratios. US Geological Survey Professional Paper 525-B:B79-B84

Paterson Scott R, Vernon Ron H, Tobisch Othmar T (1989) A review of criteria for the identification of magmatic and tectonic foliations in granitoids. J Struct Geol 11(3):349-363

Perfit MR, Brueckner H, Lawrence JR, Kay RW (1980) Traceelement and isotopic variations in a zoned pluton and associated volcanic-rocks, Unalaska Island, Alaska: a model for Fractionation in the Aleutian Calcalkaline Suite. Contrib Mineral Petrol 73(1):69-87

Petterson MG, Windley BF (1985) Rb-Sr dating of the Kohistan arcbatholith in the Trans-Himalaya of North Pakistan, and tectonic implications. Earth Planet Sci Lett 74(1):45-57

Petterson MG, Windley BF (1986) Petrological and geochemical evolution of the Kohistan arc-batholith, Gilgit, N Pakistan. Geol Bull Univ Peshawar 19:121-149

Petterson MG, Windley BF (1991) Changing source regions of magmas and crustal growth in the Trans-Himalayas; evidence from the Chalt Volcanics and Kohistan Batholith, Kohistan, northern Pakistan. Earth Planet Sci Lett 102(3-4):326-341

Pidgeon RT (1992) Recrystallisation of oscillatory zoned zircon; some geochronological and petrological implications. Contrib Mineral Petrol 110(4):463-472

Pitcher WS (1997) The nature and origin of granite. Chapman \& Hall, London

Pons J, Oudin C, Valero J (1992) Kinematics of large syn-orogenic intrusions: example of the lower proterozoic Saraya Batholith (Eastern Senegal). Geol Rundsch 81(2):473-486

Pudsey CJ et al (1985) Collision zone between the Kohistan Arc and the Asian Plate in NW Pakistan. Trans R Soc Edinburgh Earth Sci 76(4):463-479

Rapp RP, Watson EB, Miller CF (1991) Partial melting of Amphibolite Eclogite and the Origin of Archean Trondhjemites and Tonalites. Precambrian Res 51(1-4):1-25

Ringuette L, Martignole J, Windley BF (1999) Magmatic crystallization, isobaric cooling, and decompression of the garnetbearing assemblages of the Jijal Sequence (Kohistan Terrane, western Himalayas). Geology (Boulder) 27(2):139-142

Ringwood AE (1974) The petrological evolution of island arc systems (twenty-seventh William Smith lecture). J Geol Soc London 130(Part 3): 183-204 
Rudnick RL (1995) Making continental crust. Nature 378:571-578

Rudnick RL, Gao S et al (2003) The composition of the continental crust. In: Rudnick RL (ed) The crust. Treatise on geochemistry. Elsevier, Oxford, pp 1-64

Schaltegger U, Zeilinger G, Frank M, Burg JP (2002) Multiple mantle sources during island arc magmatism; $\mathrm{U}-\mathrm{Pb}$ and $\mathrm{Hf}$ isotopic evidence from the Kohistan arc complex, Pakistan. Terra Nova 14(6):461-468

Schaltegger U et al (2004) Crust-mantle interaction during Karakoram-Kohistan accretion (NW Pakistan). Goldschmidt 2004. Geochim. Cosmochim. Acta 68/11, Copenhagen

Shand SJ (1943) Eruptive rocks. Wiley, London

Sullivan MA, Windley BF, Saunders AD, Haynes JR, Rex DC (1993) A palaeogeographic reconstruction of the Dir Group; evidence for magmatic arc migration within Kohistan, N. Pakistan. In: Treloar PJ, Searle MP et al (eds) Himalayan tectonics. Geological Society Special Publications. Geological Society of London, London, pp 139-160

Sun SS, McDonough WF (1989) Chemical and isotopic systematics of oceanic basalts; implications for mantle composition and processes. In: Saunders AD, Norry MJ (eds) Magmatism in the ocean basins. Geological Society Special Publications. Geological Society of London, London, pp 313-345

Tahirkheli RAK (1979) Geology of Kohistan and adjoining Eurasia and Indio-Pakistan continents, Pakistan. Geol Bull Univ Peshawar 11:1-30

Thirlwall MF et al (1994) High-field strength element anomalies in Arc Lavas: source or process. J Petrol 35(3):819-838

Thompson AB, Connolly JAD (1995) Melting of the Continentalcrust: some thermal and petrological constraints on anatexis in continental collision zones and other tectonic settings. J Geophys Res Solid Earth 100(B8):15565-15579
Treloar PJ et al (1989) K-Ar and Ar-Ar geochronology of the Himalayan collision in NW Pakistan; constraints on the timing of suturing, deformation, metamorphism and uplift. Tectonics 8(4):881-909

Treloar PJ, Petterson MG, Jan MQ, Sullivan MA (1996) A reevaluation of the stratigraphy and evolution of the Kohistan Arc sequence, Pakistan Himalaya; implications for magmatic and tectonic arc-building processes. J Geol Soc London 153(Part 5): 681-693

Weinberg RF, Dunlap WJ (2000) Growth and deformation of the Ladakh Batholith, Northwest Himalayas; implications for timing of continental collision and origin of calc-alkaline batholiths. J Geol 108(3):303-320

Whalen JB (1985) Geochemistry of an island-arc plutonic suite; the Uasilau-Yau Yau intrusive complex, New Britain, P.N.G. J Petrol 26(3):603-632

Wilson M (1989) Igneous petrogenesis. Chapman \& Hall, London

Wolf MB, Wyllie PJ (1991) Dehydration-melting of solid amphibolite at $10 \mathrm{Kbar}$ : textural development, liquid interconnectivity and applications to the segregation of magmas. Mineral Petrol 44(34):151-179

Yamamoto H, Kobayashi K, Nakamura E, Kaneko Y, Kausar Allah B (2005) U-Pb zircon dating of regional deformation in the lower crust of the Kohistan Arc. Int Geol Rev 47:1035-1047

Zeilinger G (2002) Structural and geochronological study of the lowest Kohistan complex, Indus Kohistan region in Pakistan, NW Himalaya, Unpublished Ph.D., ETH Zurich

Zeitler PK, Chamberlain CP, Smith HA (1993) Synchronous anatexis, metamorphism, and rapid denudation at Nanga Parbat (Pakistan Himalaya). Geology (Boulder) 21(4):347-350 